\title{
Research on the Influence of Chinese Traditional Art on the Development of Russian Oil Painting Art
}

\author{
Xiaojuan Wang \\ Heihe University \\ Heilongjiang, China
}

\begin{abstract}
This paper demonstrates the great influence of Chinese painting art on Russian paintings according to the researches on the painting styles of the missionary painter, Rajashev and contemporary Russian famous painter, Yuri Kaleita. With the continuous enhancement of national strength, the relations between China and Russia are becoming more and more closed. And in this context, it is necessary to deepen the cooperation in the field of culture and art between the China and Russia. And it has become a trend. And culture and art can promote the friendship between Chinese and Russian peoples. It also can promote the continuous innovation and development of the culture and art in these two countries.
\end{abstract}

\section{Keywords—the missionary; Rajashev; Yuri Kaleita}

\section{INTRODUCTION}

In the history of human cultural communication, the cultural exchange between China and Russia is a miracle. And Sino-Russian cultural exchanges started later than Sino-Indian cultural exchange and cultural exchange between China and the West. However, the influence on the two sides is extremely profound. The Russian literature, painting, dance and other art categories had profound impacts on Chinese artists and art education. On the contrary, it was as early as in the Mongols rule period. China's culture and art had huge impacts on Russia. It can be said that the Russian civilization has contained the oriental factors in the beginning of the period. Whether it is from the national pledge or from the geographical conditions, or from the social development conditions, there are always oriental factors in the Russian state and cultural development.

The art of Russia is profound in the world. And it has great impacts on the Chinese art. In recent years, many scholars have studied the influences of Russian art on the development of Chinese art. And a few of scholars have explored the influences of Chinese art, especially the influences of traditional arts on the Russian art. The initial cultural exchange between China and Russia began in the Mongol-Yuan period. And then, in the late Ming and early Qing Dynasty, it had resumed the cultural exchanges. It continues to this day. [1] China's traditional arts, such as Chinese painting, porcelain and architecture have made a wide range of effects on the development of Russian art. To

This article is the research result of art planning "A study on the teaching innovation model of fine arts in the background of Sino-Russian cooperation ". Project No.: 2017D076 sort out the influences of Chinese traditional art on Russia and the situation of the spreading, and to show the glorious achievements of the great culture and art of China are helpful to strengthen the traditional cultural exchanges between China and Russia in the future. And it also has a certain theoretical significance for enhancing the development and enrichment of culture.

\section{THE IMPACT OF TRADITIONAL CHINESE ART ON RUSSIAN MISSIONARY PAINTERS}

The origins of cultural exchanges between China and Russia started with religious exchanges. In the middle of the 17th century, Tsarist Russia dispatched troops to invade the areas along Heilongjiang River. In 1685, Russian icons have begun to be introduced into China with the Orthodox Church after the Yaksa war. In 1727, China and Russia signed "Qiaketu Treaty". In this treaty, Russia proposed to establish the Russian Orthodox Mission in Beijing permanently. It had got the permission of the government of Qing Dynasty to make religious service for Russian prisoners of war captured in Beijing during the Battle of Yaksa. By 1864, Russia has sent a total of 14 missionaries to China. The missionary activities not only were limited to religion. It also set up a bridge of cultural exchanges between China and Russia. For example, there were many sinologists in missionaries of Russian orthodox Eastern Church in the 18th century. They were proficient in Chinese and had written generous works. And these works had deepened Russia's understanding on China. In Russia, it had created social atmosphere of "China fever". At that time, it has achieved the first large output of Chinese culture to Russia. Also, it had a lot of experts in the study of Sinology, scholars of Manchu study and Tibetologist. At the same time, with the spread of the Orthodox Eastern Church, the artistic exchange between Russia and China has been increasingly mature.

The introduction of Russian fine art works into China is the source of Sino-Russian art exchange. And the introduced Russian fine art works are represented by the Russian icons of the Orthodox Eastern Church. Russia had sent the eleventh to fourteenth missionary group to China. And there was always a professional painter with the missionary. For example, they were Rajashev, Korsa Lin, Chimutov and Igor Lev. They were registered in the history. In accordance with the instructions of the Russian government, these painters drew the Chinese folklore, people, things and 
scenery. It didn't require to pursuing the art of the work. But it must be accurate and objective. These painters made the creation on the theme of China's natural landscape and customs. Some painting styles and techniques were deeply influenced by Chinese painting art. Their works had brought "Chinese style" to the Russian art community. Then, the oriental civilization was displayed to the Russian people in the form of painting directly. There were some artists who love Chinese art in these missionaries. They brought a lot of good works, the ink, paint and paper used in the Chinese paintings back to Russia. It can be said that these missionaries have made great contribution to the SinoRussian art exchange. The representative is Rajashev.

Rajashev (1798-1865), the full name is Anton Mikhailovich Rajashev. He is first one of Russian professional painters sent to China. His most famous landscape works was "Chinese city". And this work was created in 1864. The middle of the picture is a road from the near to far. There were houses, walls, trees, characters and other contents on both sides of the road. And there were many plot description, for example, goats and donkeys were eating grass, the Chinese women was grinding the mill, the Chinese women riding a donkey, and so on. The entire screen layout was reasonable. The painter comprehensively exhibited the Chinese city and the people's life on the canvas. In addition, another work of Rajasayev was "Chinese life style". It also reflected the daily life of the Chinese people. There were two women playing musical instruments in a house. The painter had a good sense of light. And it also depicted the screen, tea and scenery outside the windows. Works had described the details in the daily life of Chinese families. And it had created a quiet and harmonious atmosphere. The painter deliberately avoided the laws of visual perspective of oil painting. However, it was close to the way of Chinese painting. It can be said that this painting embodies the artists' understanding and pursuit of Chinese art in a certain extent. Rajashev's paintings in China were not limited to the landscape theme. And he also created a lot of portraits. He painted the portraits of the princes of China. And then, he gave them these portraits. And some works also used the form of fan. China's customs and some characteristics of Chinese painting were used in the performance of Rajasayev's works. And the screen had a strong Chinese art. The works of Rajashev clearly reflected the influences of Chinese traditional art on Russian paintings. As the first Russian painter who came to China, his influences and significance in Sino-Russian art exchange were enormous. He brought the Russian oil painting to China. According to his works, he brought the Chinese customs back to Russia. [2]

\section{THE INFLUENCES OF CHINESE TRADITIONAL ART ON CONTEMPORARY RUSSIAN PAINTERS}

When it comes to contemporary Russian artists, you can't ignore Yuri Carla. They had made great influences on Chinese traditional art. Yuri Kaleita was born in 1957, and graduated from the Repin Academy of Fine Arts in 1989. Then, he stayed in school. Yuri Kaleita was good at learning and absorption. He had the merits of many masters, and set a unique style of painting. He made the fusion of the art styles of Velasquez, Modigliani, Serov and other western artists in his works. It was worth mentioning that there was a Chinese painting freehand spirit in the works of Yuri Kaleita.

Carla Tatta is very fond of China, and likes to communicate with Chinese artists. He has gone to China for many times to perform exhibitions, and to study the traditional Chinese art, especially freehand brush work. Ka Lutai was good at the performance of portraits. His portrait works highlighted the charm of the characters. And the works focused on the expression of meaning with a strong writing. And the works were refining with color. Kaleita was influenced by the traditional and classical oil paintings. The painting works were with the sense of the Russian realism oil paintings. And the eastern exquisite artistic spirit was integrated into the works. Therefore, the works of Kaleita were both classical and romantic. The freehand brushwork was the salient feature of his works.

There were many contemporary Russian artists influenced by the traditional Chinese art. The representatives were the teachers in Chinese colleges and universities. For example, Kondarov had taught in the Jinan University in Shandong. He said that the cultural heritage of the nation could attract any artist. In the works, you couldn't see the prosperity of China's economy. There were no skyscrapers and highways in works. It described the ancient culture spirit with the characteristics. And China had not been europeanized. There were remote villages, narrow streets, old Beijing and Shanghai food market. [3]

As an ancient and civilized country, China's traditional culture was profound. China's traditional culture could provide Chinese people with self-esteem and selfconfidence. The traditional Chinese culture was business card of China for the world to understand China. There was an imbalance in cultural exchanges between China and Russia in the Qing Dynasty. Although the culture and art of China was brought to Russia in religious and other means. The depth and breadth of the spread of Russian culture and the impacts on Chinese culture and arts are far more than China. There were many reasons such as the rulers, the national strength, and the social development and so on. There was a certain imbalance. The traditional Chinese art was deeply loved by the Russian people, especially the nobility. These traditional arts were one of the effective ways for Russia to understand China. This was also an important factor in the spread of Chinese culture and art in Russia. Today, the international exchanges and cooperation were increasingly close. The development of culture and arts was inseparable from the exchange and learning. Chinese art had attracted more and more artists' attention and love in the world. More and more artists liked to use the Chinese elements in their own artistic creation.

\section{CONCLUSION}

It is believed that China-Russia relations are increasingly close with the continuous increase of China's national strength. The cooperation in politics, economy, energy and other aspects continues deepening. In this context, it is necessary to deepen Sino-Russian cooperation in the field of 
culture and arts. And it has become a trend. And then, more Russian people have the opportunities to understand the Chinese art. Then, they can understand China. Cultural and artistic exchanges will bring more cooperation in areas. It shows Chinese unique oriental images through cultural exchanges. It builds a bridge between the two peoples with culture and art to explore the effective mode of SinoRussian cultural and artistic exchange. It is necessary to establish the sustainable development of cultural exchanges, and to promote the continuous innovation and development of the art in two countries. And it has promoted the continuous development of friendships between China and Russia.

\section{REFERENCES}

[1] Xiao Yuqiu. On the imbalance of cultural exchanges between China and Russia in the Qing Dynasty [J]. Journal of History. 2008. 4

[2] Jiang Hongsheng, Li Jiazhen, Li Yun. "Chinese and Foreign Fine Arts in Fifty Years: Communication, Influences and Comparison". China Reading Weekly, October 13, 1999

[3] The art website of Qingyun club. http://www.qingyunge.com/2013/0308/2107.html

[4] Kuang Yuxia, Wang Juan. On Sino - Russian cultural exchange [J]. Journal of Urumqi Vocational University. 2010 (01)

[5] Wang Chongmei. Reflection on the oriental characteristics of Russian culture [J]. Foreign Theoretical Trends. 2010

[6] Xiao Yuqiu. Russian missionaries and Sino - Russian cultural exchange in the Qing dynasty [M]. Tianjin People's Publishing House. 2009

[7] Qin Siying, Ma Zhenqing. The analysis on Kaleita' painting art---the Russian contemporary oil painter [J]. Art \& Technology, 2014

[8] Wang Zhong. The Russian painter---Yuri Kaleita absorbed the freehand spirit of the Chinese painting [J]. Russian Literature and Art, 2008 